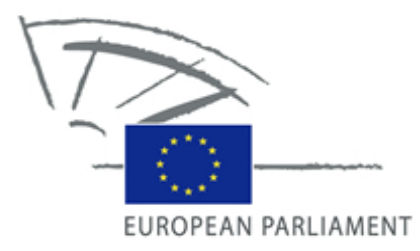

DI RECTORATE GENERAL FOR I NTERNAL POLI CI ES

POLI CY DEPARTMENT A: ECONOMI C AND SCIENTI FI C POLICY

\title{
Towards a Genuine Economic and Monetary Union
}

\section{NOTE}

\begin{abstract}
While the European Central Bank has managed to calm markets, the persistent political cacophony and institutional inability to conduct coherent macroeconomic policies at the euro level have undermined trust in the viability of the euro.

The paper reviews the arguments, which show EMU as an indispensable complement to market integration and then assesses ideas for reforming the euro area's governance with respect to Banking Union, Economic Union and the crucial question of democratic legitimacy
\end{abstract}


This document was requested by the European Parliament's Committee on Economic and Monetary Affairs.

\section{AUTHOR}

Stefan COLLIGNON, Scuola Superiore Sant'Anna, Pisa and Centro Europa Ricerche (CER), Rome

With research assistance performed by Piero ESPOSITO

\section{RESPONSI BLE ADMI NISTRATOR}

Rudolf MAIER

Policy Department Economic and Scientific Policies

European Parliament

B-1047 Brussels

E-mail: Poldep-Economy-Science@europarl.europa.eu

\section{NGUI STI C VERSI ONS}

Original: EN

\section{ABOUT THE EDITOR}

To contact the Policy Department or to subscribe to its newsletter please write to:

Poldep-Economy-Science@europarl.europa.eu

Manuscript completed in December 2012.

Brussels, (c) European Union, 2012.

This document is available on the I nternet at:

http://www. europarl. europa.eu/activities/committees/studies. do?language=EN

\section{SCLAI MER}

The opinions expressed in this document are the sole responsibility of the author and do not necessarily represent the official position of the European Parliament.

Reproduction and translation for non-commercial purposes are authorised, provided the source is acknowledged and the publisher is given prior notice and sent a copy. 


\section{CONTENTS}

1. I NTRODUCTION 6

2. THE RATIONAL OF EUROPEAN MONETARY UNION 7

2.1. The inconsistent quartet 7

2.2. Transaction costs 8

2.3. Optimum currency area theory 8

3. HOW MONETARY UNION WORKS 10

4. BANKING UNION 12

4.1. From micro to macro-prudential supervision 13

4.2. The dangers of deleveraging 14

4.3. A single supervisory system 16

5. ECONOMIC UNION $\quad 19$

5.1. Regional imbalances 19

5.2. Macroeconomic aspect of a European Social Union 21

6. FISCAL UNION $\quad 24$

6.1. The efficiency and legitimacy of budgetary policy in Europe 25

6.2. A budget for the euro area? 26

7. A DEMOCRATIC POLITICAL UNION 28 


\section{EXECUTI VE SUMMARY}

- Europe stands at a cross road. While the European Central Bank has managed to calm markets, the persistent political cacophony and the institutional inability to conduct coherent macroeconomic policies at the euro level have undermined trust in the viability of the euro. The contradiction between the economic and the political dimensions of European integration is the fundamental cause behind the Euro crisis.

- The Monetary Union is an indispensable element of European integration, for without monetary stability a fully integrated internal market is unsustainable. The rational for monetary integration is derived from three main arguments: (i) the theory of inconsistent quartet first derived by Padoa-Schioppa (1987) from the MundellFleming model of open economics, (ii) the private sector arguments of reducing transaction costs in the single market, and (iii) the optimum currency area theory.

- A currency area is not a fixed exchange rate system. It is a payment union. The euro area functions exactly as any other currency area. Like all institutions, money can only exist because there is a critical mass of trust and mutual reliability in society. Maintaining trust in the euro and confidence in the reliability and enforceability of financial contracts, must be the highest priority for ensuring the sustainability of the monetary union.

- A genuine monetary union is more than a policy rule for issuing money. Money is supplied by banks and an efficient banking union is crucial for the proper functioning of EMU. Lack of harmonisation has maintained the idiosyncrasies of national banking systems and prevented the genuine integration of financial markets. A unified banking supervision must overcome these shortcomings.

- Micro-prudential supervision is a partial-equilibrium conception of financial regulation; it does not cover the external effects on the economy's general equilibrium that macro-prudential supervision seeks to avoid. The two most important externalities are the danger of bank-runs and credit crunches causing output losses and unemployment in the real economy.

- The traditional micro-approach of setting minimum capital requirements is insufficient to preserve the stability of the system, because it does not take into consideration whether banks adjust by raising new capital or by shrinking assets. The simultaneous attempt by banks to deleverage is a major cause for recessions and slow growth after financial crises.

- In open competitive market-driven systems, banking supervision benefits if the central bank is in charge. Putting the ECB in charge, reflects the realities of European Monetary Union.

- Macro-prudential supervision is one side of avoiding systemic risks; reducing the likelihood of regional booms and busts in the real economy is the other side. Avoiding macroeconomic imbalances can reduce these dangers ex ante, while fiscal policy may be needed to stabilise the economy ex post.

- One argument against EMU is the 'one size does not fit all' slogan, which was supported by the Walter's critique according to which inflation differentials cause booms and busts through their effect on real interest rates. However, rising prices also undermine competitiveness. Our empirical tests do not find any confirmation of the Walter's critique, but support the hypothesis of excessive imbalances being selfcorrecting through competitiveness pressures.

- Nevertheless, relative costs and wage setting create incentives for investment and growth. We calculate an index for competitiveness based on a novel concept of equilibrium unit labour costs that shows northern Member States are generally below equilibrium and the south above. While the standard adjustment mechanism 
<smiles>[C-]1C=C[CH-]1</smiles> 


\section{I NTRODUCTI ON}

Europe stands at a cross road. The old ways of governing the euro did not work well, but the new system is incomplete. Under the pressure of the crisis, the European Union has taken important and far-reaching steps to overcome malfunctionings and improve the governance of European Monetary Union. However, the success of these measures remains in doubt. Despite occasional intervals of relative quiet in financial markets, the crisis has reemerged repeatedly, each time with more serious threats to the survival of the monetary and the European Union. No doubt, the European Central Bank has managed to calm markets, but the persistent cacophony, caused by national governments and irresponsible statements from local politicians, but also by the institutional inability to conduct coherent macroeconomic policies at the euro level, has undermined trust in the viability of the euro (Collignon, 2012; Collignon, Esposito, Lierse, 2011). Hence, new approaches need to be found to ensure the sustainability of the European project.

The J une 2012 European Council has asked the President of the European Council, together with the Presidents of the Eurogroup, the ECB and the European Commission, to develop 'a specific and time-bound road map for the achievement of a genuine Economic and Monetary Union'. ${ }^{1}$ The Van Rompuy (2012) Interim Report Towards a Genuine Economic and Monetary Union was presented on 12 October 2012 and has concentrated on four main building blocks:

- An integrated financial framework

- An integrated budgetary framework

- An integrated economic policy framework

- Democratic legitimacy and accountability of decision making

While the Report contains many practical measures, which may be adopted as policy tools by the December 2012 European Council and lead to a Treaty re-negotiation later on, the debate about the future of the euro area is missing a comprehensive vision that deals with the fundamental weaknesses of the euro area's governance. The main problem is that while the project of economic and monetary integration was remarkably successful (after all, the euro still exists after three years of unabated pounding, shocks and crises), political union has been limping behind and national governments have, on balance, made the crisis worse. The contradiction between the economic and the political dimensions of European integration is the fundamental cause behind the Euro crisis. Unless this contradiction is solved, the demise of the European Union can hardly be avoided.

This note will, therefore, discuss first why monetary union is an essential dimension of economic integration, without which the single market cannot exist; it will then look at how financial, economic and budgetary policy issues overlap; it will conclude with the unsolved issue of democracy in European policy making.

1 http://www.consilium. europa.eu/uedocs/cms Data/docs/pressdata/en/ec/131388. pdf. 


\section{THE RATIONAL OF EUROPEAN MONETARY UNION}

At a time when trust in the European Union has fallen to its lowest ever level $(31 \%)^{2}$, when policy makers are debating Grexit and German domination over Europe, when demands for the re-nationalisation of policies are entering the political mainstream, and not only fringe parties are calling for the break-up of the euro area, ${ }^{3}$ it may be useful to recall why European Monetary Union is an integral part of the European project.

A European currency was from the beginning one of the objectives of European integration. J ean Monnet, Robert Triffin, Helmut Schmidt, Valery Giscard d'Estaing (and even his father) called for it already in the 1950s, but during the Bretton Woods regime of international monetary stability there was little urge to move on this front. This changed in the 1970s. European integration had entered a phase of severe stagnation due to high monetary instability, high inflation and large exchange rate volatility. The instability inhibited investment, lowered growth, contributed to rising unemployment and pushed up public debt. A first response to the increasing economic problems was the creation of the European Monetary System in 1979. It was followed by the passing of the European Single Act in 1986-1987, which completed the European Economic Community and generated a fully integrated internal market. By abolishing barriers to trade, new opportunities were expected to re-invigorate the European economy. However, it quickly became clear that a single market could not function properly without monetary stability. For otherwise volatility in exchange markets and relative price changes unrelated to the quality of products would always distort the competition among firms. Thus, monetary union was seen as an indispensable complement to the full integration of the internal market.

The rational for monetary integration drew on three main arguments: (i) the theory of inconsistent quartet first derived by Tommaso Padoa-Schioppa from the Mundell-Fleming model of open economics, (ii) the private sector arguments of reducing transaction costs in the single market, and (iii) the optimum currency area theory.

\subsection{The inconsistent quartet}

Padoa-Schioppa (1987) argued that the four policy objectives of achieving free movements of goods and services, free flow of capital, fixed exchange rates, and conducting national monetary policies were inconsistent. In an efficient market the competition between firms is supposed to allocate resources to producing the output which maximises consumer utility. Given that capital, together with labour, is one of the most important factors of production, a single market requires the free flow of capital, for otherwise the allocation of funds is distorted. However, an integrated internal market also requires fixed exchange rates, for otherwise the movements of exchange markets would continuously shift the relative prices of goods without reflecting the quality of products and their utility for consumers. The European Monetary System (EMS), which prevailed between 1979 and 1992, was an attempt to stabilise exchange rates. However, in such a fixed exchange rate regime with free flows of capital, monetary authorities had to set interest rates in such a way that they attracted capital and stabilised foreign exchange reserves, especially when current account deficits required balancing capital inflows. As a consequence, Germany, the largest country with regular current account surpluses, enjoyed lower interest rates than the rest of the system and its currency became the benchmark for monetary policy for the entire currency bloc. This meant that national monetary policies aiming at stabilising exchange rates lost their autonomy and had to follow the policies of the key currency to

Standard Eurobarometer 77, Spring 2012.

See: Valentina Pop, 'German bank tables plan for parallel Greek euro';

http://euobserver.com/economic/116325 (accessed 13.11.2012). 
which they were pegged. Thus, under the EMS, the Deutschmark was the key currency and only Germany was able to conduct autonomous national policies. However, then as now, Germany's 'national interests' did not always coincide with the common interests of European citizens (including, of course, German citizens). National sovereignty for other European economies was constrained. Furthermore, the need to stabilise exchange rates through DM-pegging required frequent and potentially large variations in interest rates, which distort the level playing field for capital costs in the European internal market. Thus, a fixed exchange rate regime is not consistent with a single internal market. The only way to overcome this obstacle was to give up national monetary policies and unify them under the authority of the European Central Bank.

\subsection{Transaction costs}

A correlated argument was made by firms in the private sector, who argued that the existence of different currencies imposed unnecessary transaction costs to European firms. Other than the macroeconomic cost of pegging exchange rates and the capital cost distortions resulting from interest rate differentials, European companies incurred costs for the currency and liquidity management of their treasury, and they had to pay exchange fees and other hedging costs against exchange rate volatility that rose with the length of the time horizon of investment. Furthermore, the costs of information increased, too, due to the lack of market transparency for consumers and suppliers, which inhibited efficient corporate marketing strategies. Finally, exchange rate variations did not only systematically distort relative price levels, but also generate uncertainty for investment decisions, which lowered the potential for trans-border investments. These were powerful arguments which practical men and women in the private sector put forward when they demanded a single currency (Collignon and Schwarzer, 2002).

\subsection{Optimum currency area theory}

Optimum currency area theory goes back to the famous paper by Robert Mundell (1961). He argued that, in the case of asymmetric shocks and structural rigidities in the labour market, the exchange rate could be an important tool to restore economic equilibrium. However, with a single currency this adjustment channel was not available. The question of optimality was then, what kind of shocks would hit a currency area. Mundell was very clear that if one took the argument to its logical conclusion, each and every product and region would require its own currency and he concluded that the formation of a monetary area was a political rather than an economic decision. Nevertheless, optimum currency area theory became a tool for arguing why one should not join or accept particular Member States in monetary union. In the 1990s many economists used the theory as a tool for analysing whether particular Member States of the European Union should or should not join monetary union, thereby standing Mundell's argument on its head. This stood in clear contradiction to the original intentions of Mundell (see Mundell, 1998) and the theory of the inconsistent quartet put forward by Padoa-Schioppa (1987).

One of the main arguments that emerged from this discussion was that labour market flexibility could serve as a major criterion for optimum currency areas. Euroskeptics often claimed that labour mobility in the United States was higher than in Europe and therefore Europe would not be an optimum currency area (Eichengreen, 1991). However, using the USA as a benchmark had no theoretical foundation; while empirical estimates often took the movements of workers across borders as a measure for labour market flexibility, this approach underestimated the role of structural wage gaps between more and less developed Member States in the European Union. The experience of the first decade of monetary union has also shown a net improvement in workers' mobility. Because the Euroskeptical interpretation of the optimum currency area argument did not really stand up 
Towards a Genuine Economic and Monetary Union

to reality checks, pro-euro economists have argued that the optimality of a currency area is endogenous, ie. that the mechanisms of a monetary economy will generate their own adjustment (Masini, 2012). In other words, the issue has never been whether 'one size fits all', because 'one size makes all fit'.

Most of the theories and arguments of the 1990s regarding European Monetary Union focused on exchange rate stability, which was not surprising given that the volatility in European exchange markets during the $1970 \mathrm{~s}$, ' $80 \mathrm{~s}$ and '90s was a major obstacle to the integration of the European single market. Monetary theories focused on the function of money as a means of exchange. However, as Robert Mundell (1998) and Charles Goodhart (1998) have pointed out, money also has a political dimension. In fact, the concrete implementation of European Monetary Union, through the setting up the European Central Bank went far beyond creating a fixed exchange rate regime. While monetary union is an integrated monetary economy, which works like any other currency area in any nation state, the failure by economists and policy makers to recognise the political implications of monetary union has contributed to important policy mistakes during the recent Euro crisis.

PE 492.455

9 


\section{HOW MONETARY UNION WORKS}

A currency area is not a fixed exchange rate system. It is a payment union. This means a currency area is the territory where credit contracts can be enforced and extinguished by paying the legally defined and generally accepted currency, which is legal tender (Collignon, 2012b). Thus, it should be clear that money is more than a means of exchange - it is a means of payment that emerges from credit contracts and requires legal foundations. In practical terms, base money, i.e. legal tender, is issued by the central bank. To be precise, it is created when the Eurosystem gives a credit against collateral to commercial banks or buys financial assets outright. How much money commercial banks get from the central banks constitutes the domestic budget constraint of an economy. Banks hold this money as deposits on their central bank account, or they exchange deposits against bank notes which they supply to their clients. Either way, base money is a liability of the central bank.

In a fixed exchange rate system the budget constraint functions differently. In order to make international payments, i.e. payments in a different currency, domestic currency must be changed into foreign currency. Foreign exchange may be earned by net exports or net capital imports; beyond this amount foreign payments can only be made by using foreign exchange reserves provided by the central bank. Hence, the external budget constraint of any economy is the foreign exchange reserve held by the central bank. Yet, foreign reserves are an asset in the bank's balance sheet, while base money is a liability.

It is therefore clear, that making domestic and foreign payments are two different constraints, which do not depend on the borders of states, but on the functionality of having access to either base money or foreign reserves. In a fixed exchange rate regime, the foreign exchange constraint is binding; in a currency union, the domestic money constraint is binding. Interpreting a monetary union as a fixed exchange rate area, constitutes, therefore, a category mistake which confuses the internal and external budget constraints.

The euro area functions exactly as any other currency area, even if its legal framework is not established by a single state, but by the Treaties of the European Union. When European Monetary Union started on 1 January 1999, the Euro became legal tender in the participating Member States (Art. 3(4) TEU). Previously existing monetary laws in Member States were abrogated. The European Central Bank (ECB) was set up as the bank of banks and as the ultimate organ and head office for the conduct of monetary policy. The existing national central banks (NCB) were effectively merged with the ECB to form the Eurosystem. In business, a merger is a combination of two companies where the less important company loses its identity and becomes part of the more important corporation, which retains its identity. ${ }^{4}$ This is precisely the status of NCBs, which the ECB uses for the execution of its policies, even if the national central banks are the shareholders of the ECB.

The Eurosystem is the only institution to issue money. ${ }^{5}$ The ECB and the Eurosystem also function as the bank of banks, as Article 17 of Protocol (No 4) to the European Treaties says: 'In order to conduct their operations, the ECB and the national central banks may open accounts for credit institutions, public entities and other market participants and accept assets, including book entry securities, as collateral.' In addition, the Treaty (Art

4 The Free Dictionary, Mergers and Acquisitions; http://legaldictionary.thefreedictionary.com/Mergers+and+Acquisitions dictionary.thefreedictionary.com/Mergers+and+Acquisitions (accessed 18.11.12).

5 The Treaty (TFEU art.126.1) stipulates: 'The European Central Bank shall have the exclusive right to authorise the issue of Euro banknotes within the Union. The European Central Bank and the national central banks may issue such notes. The banknotes issued by the European Central Bank and the national central banks shall be the only such notes to have the status of legal tender within the Union.' 
127(2) TFEU) and its Protocol 4 (Art. 3) explicitly stipulate the joint task to promote the smooth operation of payment systems'.

The Treaty is also clear how money is created (Protocol (No 4), Art. 18.1):

'In order to achieve the objectives of the ESCB and to carry out its tasks, the ECB and the national central banks may:

- operate in the financial markets by buying and selling outright (spot and forward) or under repurchase agreement and by lending or borrowing claims and marketable instruments, whether in Euro or other currencies, as well as precious metals;

- conduct credit operations with credit institutions and other market participants, with lending being based on adequate collateral.'

Finally, the ECB has legal personality and is independent from all other institutions. While NCBs are 'the sole subscribers to and holders of the capital of the ECB' (Protocol (No 4), Art. 28), the ECB is liable for all actions of the Eurosystem, and profits and losses are the distributed to the shareholders of the ECB in proportion to their paid-up share capital. ${ }^{6}$ Hence, there can be no doubt that the euro area is a currency area as defined above.

Yet, like all institutions, money can only exist because there is a critical mass of trust and mutual reliability in society. When trust vanishes, money disappears. When trust relationships are trivialised, a common currency becomes impossible. Maintaining confidence in the reliability and enforceability of contracts, especially financial contracts, must be the highest priority for ensuring the sustainability of the monetary union. This means that money is not only a spontaneous creation by markets, but that it has a public goods character which requires a legal framework and government. When Member State governments do not respect the agreements and compacts made in Europe, or when senior politicians and government officials put in doubt their commitment to the euro and preserving the functionality of the payment union, the end of European Monetary Union can no longer be discarded.

Financial markets reflect these doubts with professional realism. During the recent euro crisis, national governments and parliaments, even some central bankers and constitutional courts, have repeatedly undermined the trust and confidence of markets and citizens. For the time being, they have been bailed out by the ECB and this has stabilised the situation. However, as long as Europe's political system (or rather non-system) continues to generate confidence shocks and allows partial interests to prevail over the collective interest of all European citizens, a genuine European Monetary Union will not exist.

6 Protocol (No 4), Art. 33: 'In the event of a loss incurred by the ECB, the shortfall may be offset against the general reserve fund of the ECB and, if necessary, following a decision by the Governing Council, against the monetary income of the relevant financial year in proportion and up to the amounts allocated to the national central banks in accordance with Article 32.5.' 


\section{BANKI NG UNION}

A genuine monetary union is more than a policy rule for issuing money. Defining a currency area as a payment union focuses the view on the important role which banks (i.e. credit institutions) assume in an economy. Payments are made by using bank services or in cash, but in modern economies cash is always obtained from the central bank and distributed through the network of commercial banks. ${ }^{7}$ Money is supplied by granting credit and the central bank needs commercial banks as the monitor for creditworthiness (Riese, 2001).

The European Union has approximately 8,000 banks, ${ }^{8}$ representing $53 \%$ of global assets, and 27 different national regulatory systems; about 6000 banks are registered in the euro area alone. The Second European Banking Directive in $1989^{9}$ has opened national markets, but it has not set up a single rule book. ${ }^{10}$ Even the present banking directive of 2006 defends heterogeneity:

'It is appropriate to effect only the essential harmonisation necessary and sufficient to secure the mutual recognition of authorisation and of prudential supervision systems, making possible the granting of a single licence recognised throughout the Community and the application of the principle of home Member State prudential supervision. Therefore, the requirement that a programme of operations be produced should be seen merely as a factor enabling the competent authorities to decide on the basis of more precise information using objective criteria. ${ }^{\prime 11}$

The effective lack of harmonisation has maintained the idiosyncrasies of national banking systems and prevented the genuine integration of financial markets.

A new Commission Proposal finally draws the conclusion (for CRDIV (COM(2011)453) in recital 10:

'It is appropriate to effect harmonisation which is necessary and sufficient to secure the mutual recognition of authorisation and of prudential supervision systems, making possible the granting of a single licence recognised throughout the Union and the application of the principle of home Member State prudential supervision.'

The variety of supervision regimes has also encouraged regulatory arbitrage rather than market efficiency and the close (and often also closed) local networks of economic, financial and political elites have generated distortions in capital allocation, which have severely threatened financial stability not only in individual Member States, but in the euro area as a whole. While it is true that each Member State has its own history and specific banking traditions, and that this variety will not disappear, there is nevertheless an urgent need to

7 Milton Friedman (1969) once proposed the thought experiment that a helicopter comes and distributes printed bank notes. This served his argument that prices are proportional to money supply, but unfortunately no trace of the helicopter has ever been found.

8 See ECB data, http://www.ecb.int/stats/pdf/money/mfi/mfi_latest.pdf?c8cdd3c27700bb9eeea30791c93c0a9e.

9 Second Council Directive 89/646/EEC of 15 December 1989 on the coordination of laws, regulations and administrative provisions relating to the taking-up and pursuit of the business of credit institutions and amending Directive 77/780/EEC (OJ No L 386, 30.12.1989, p. 1), as amended by Directive 92/30/EEC (OJ No L 110, 28.4.1992, p. 52), repealed.

10 As the European Commission (1997) reported: 'Community law has not, however, harmonised the content of banking activities, with a few exceptions such as some aspects of consumer credit. It is likely, therefore, that a credit institution wishing to carry on its activities in another Member State will be confronted with different rules applicable both to the service itself and to the conditions in which it may be offered and marketed. It suffices, for example, to think of the variety of national rules applicable to loans.'

11 Recital 7 of Directive 2006/48/EC of the European Parliament and of the Council of 14 June 2006 relating to the taking up and pursuit of the business of credit institutions (recast); OJ No. L 177, 30.6.2006, p.1, as last amended by the Act concerning the conditions of accession of the Republic of Croatia and the adjustments to the Treaty of the European Union, the Treaty on the Functioning of the European Union and the Treaty establishing the European Atomic Energy Community - 3. Financial Services, OJ No. L 112, 24.4.2012, p.42. 
establish a level playing field in banking by setting up a unified and centralised supervision structure at the level of the euro area. This will not be easy, as partial interests will seek to retain their regulatory advantages. ${ }^{12}$

This task of supervision will now be attributed to the European Central Bank. However, while this new responsibility strengthens the potential power of the ECB, the only functioning federal authority in the EU, there is a risk of overload in terms of expectations and policy claims. Ultimately, the ECB will only be able to function effectively and maintain its independence, if it can work with a political authority that is capable of acting without delay in a crisis and can rely on the democratic acceptance of its decisions by European citizens. Despite brave talk in the Van Rompuy Interim Report (European Council 2012) about democratic legitimacy and accountability of decision making, the euro area is far from such an institutional balance.

What does the banking union envisaged by the European Commission consist of? For the moment, the banking union rests on four pillars: a single rulebook; a single European supervisory mechanism for banks; single bank resolution mechansim, and a deposit guarantee mechanism (European Comission, 2012). However, banking supervision is by far the most important element.

\subsection{From micro to macro-prudential supervision}

An integrated banking supervision is the foundation of a genuine banking union. Creating a level playing field for 8000 banks in Europe should eliminate opportunities for regulatory arbitrage. Traditionally, banking supervision was a task for national authorities. Over the years some forms of cooperation between national supervisors have developed through the exchange of information and other informal procedures, but the euro crisis has clearly revealed that this regime could not prevent serious malfunctioning.

Up until the crisis, banking supervision largely focused on capital requirements and therefore had an excessive bias towards micro-prudential financial regulation, which meant that national supervision aimed at preventing failures of individual financial institutions. Such failures can be costly in terms of profits and welfare when deposit guarantee schemes, other banks or the government or even the central bank have to shoulder the cost of guaranteeing the bank's deposit liabilities. It is therefore understandable that European authorities have concentrated on banking regulation with a focus on capital requirements. The Commission proposes ('CRD IV') that banks should hold more and better capital to resist future shocks (European Commission, 2011) and argues that financial institutions entered the crisis with capital that was insufficient both in quantity and quality, leading to unprecedented support from national authorities. It thereby translates international standards on bank capital agreed at the G20 level (most commonly known as the Basel III agreement) into European law. But, while the increase in capital requirements is certainly useful, implementing stricter controls in the middle of a severe crisis can be counterproductive, if one does not take into account the external effects and unintended consequences the new rules may generate.

Micro-prudential supervision is a partial-equilibrium conception of financial regulation; it does not cover the external effects on the economy's general equilibrium that macroprudential supervision seeks to avoid. The most important externality is the danger of bank-runs threatening the systemic stability of the banking system as a whole, and credit

12 In Germany, there is already a debate that 'small' and non-systemic banks (among which one now also counts Commerzbank) should not be subject to European supervision. The reason is that Germany has many small banks (especially Sparkassen), which are closely connected to local businesses and it is feared that European supervisory standards would undermine the strength of Germany's Mittelstand and industry. 
crunches causing output losses and unemployment in the real economy. The traditional micro-approach is insufficient to safeguard the financial system as a whole.

The problem is the following: banks finance themselves through clients' deposits, or borrowing from other banks or by obtaining liquidity from the Central Bank. A bank run occurs when the banks' clients lose trust in the financial soundness of their bank and large numbers of customers withdraw their deposits at the same time and either demand cash or transfer the funds into other assets. With fractional reserve holding, the bank will then quickly run out of cash. These withdrawals can generate a self-fulfilling prophecy (or positive feedback loop) as the withdrawals increase the likelihood of default, thus triggering further withdrawals. This can destabilise the bank to the point where it runs out of cash and thus faces sudden bankruptcy (Diamond and Dybvig 1983). But when this financial institution has important linkages to other banks, the run on one bank can cause a systemic bank run on all banks, which will threaten the stability of the whole system. Furthermore, the breakdown of trust is likely to freeze the interbank market, so that the central bank has to step in and provide the required liquidity to the banking system.

One way to deal with this danger is insuring depositors against loss. EU legislation already guarantees bank deposits in any Member State up to EUR 100,000 per depositor if a bank fails. The Commission has proposed to go further with a harmonisation and simplification of protected deposits, faster pay-outs and improved financing of schemes, notably through ex-ante funding of deposit guarantee schemes and a mandatory mutual borrowing facility between the national schemes. The idea behind this proposal is that if a national deposit guarantee scheme finds itself depleted, it can borrow from another national fund. This would be a first step towards a pan-EU Deposit Guarantee Scheme (Commission, 2012). However, the legislative process is not advancing fast, because Member States resist paying for each other. Thus, as so often, collective action problems are blocking welfare improvements in the European Union.

The Commission proposal is probably not going far enough in creating a genuine banking union. In the United States banking problems, including resolutions in cases of insolvency, are taken care of at the federal level. The Federal Deposit Insurance Corporation (FDIC) covers losses and transfers operations from failing banks to other, stronger institutions. For example in Nevada, which is of similar size as I reland, the FDIC closed in 2008-2009 11 banks with over USD 40 billion or about $30 \%$ of state GDP, but the final losses caused by the rescues and restructuring operations amounted to USD 4 billion or $3 \%$ of GDP. By contrast, the fiscal cost (which includes bank recapitalisations and asset purchases) of Ireland's banking crisis amounted to $41 \%$ of GDP (Laeven and Valencia, 2012). Thus, the federal insurance mechanism provided Nevada with a shock absorbing mechanism, which reduced overall costs and prevented a banking crisis (Gros, 2012).

A genuine banking union in Europe would require a similar union-wide resolution mechanism. Such mechanism should not be financed by nation state budgets, for this would generate only the usual collective action gridlock. A more efficient and equitable funding method would be through a European tax or at least statutory contributions paid by all 8000 banks into a European rescue fund.

\subsection{The dangers of deleveraging}

While the academic literature has long established that deposit insurance can prevent bank runs, government-insured deposits will also create tax payers' exposure to bank losses and generate moral hazard opportunities for bank managers. This may explain why minimum capital requirements have often been the preferred regulatory instrument, because capital regulation forces banks to internalise the losses of their assets and thereby reduces the likelihood of moral hazard. This seems the road now taken by the European Commission, 
too. ${ }^{13}$ However, the exclusive focus on capital ratios can cause a credit crunch, which translates into a recession and further deteriorates banks financial position. Such regulation would defeat its purpose.

The difficulties arise from unintended consequences caused by deleveraging, which Hanson et al. (2010) explained in the following example ${ }^{14}$ :

'Consider a bank with assets of $\$ 100$ that is financed with insured deposits and some amount of capital. Suppose that the regulator can check up on the bank once a quarter. Suppose further that the volatility of the bank's assets is such that with probability 99.5 percent, the assets do not decline in value by more than 6 percent during a quarter. Then if the goal of policy is to reduce the probability of bank failure [...] to 0.5 percent, this can be accomplished by requiring the bank to have capital equal to 6 percent of its assets as a cushion against losses.[...] An important element of existing capital regulation is the presumption that a bank will take immediate steps to restore its capital ratio in the wake of losses.[...] Suppose the bank starts out with capital of $\$ 6$, but then over the next quarter experiences losses of $\$ 2$, so that its capital falls to $\$ 4$. If the volatility of its assets remains unchanged, in order for its probability of failure over the subsequent quarter to stay at 0.5 percent, it would need to bring its capital ratio back up to 6 percent. It could do so in one of two ways: either by going to the market and raising $\$ 2$ of fresh capital, or by leaving its capital unchanged and shrinking its asset base to $\$ 66.67$ (that is, $4 / 66.67=6$ percent).$^{\prime}$

This shrinking of the asset base is called deleveraging and is a major cause for recessions and slow growth after financial crises.

The problem with exclusive micro-prudential regulation is that prompt corrective actions force banks to restore their capital ratio without taking into consideration whether they adjust via the numerator or the denominator, i.e., by raising new capital or by shrinking assets. In the individual case, asset shrinking by loss makers increases the market share of healthy banks and crowds out bad banks. That is desirable. However, if a large fraction of the financial system is in difficulty, a simultaneous attempt by many institutions to deleverage is likely to be damaging to the economy that needs to be avoided. The purpose of macro-prudential financial regulation is to control the externalities and social costs associated with excessive balance sheet shrinkage on the part of multiple financial institutions after they were hit by a common shock.

How can that best be done? The case for macro-prudential regulation hinges on two questions: (i) What are the costs imposed on society when many financial firms are shrinking their assets at the same time? (ii) Why do individual banks not properly internalise these costs by raising fresh capital after they are hit by a bad shock, thereby alleviating their need to deleverage? These two questions are interconnected. ${ }^{15}$

Deleveraging generates two kinds of costs: credit crunch and fire-sale effects. If banks shrink their assets by cutting new lending, corporate firms find credit more expensive and reduce investment and employment. The credit crunch then contracts the economy. Furthermore, if a large number of banks shrink their assets simultaneously by dumping the same kind of securities, as happened after the US crisis in 2007/2008 or during the Greek crisis, the price of these securities can drop sharply (for evidence see Collignon, 2012c). This affects all balance sheets negatively, first of all of course in the banking sectors, but also for corporations and households. Hence, fire-sale and credit crunch mutually condition

\footnotetext{
13 Deposit Guarantee Schemes and Resolution regulation do not address the issue of deleveraging

14 The description of the example is directly taken from Hanson et al. (2010).

15 See Hanson et al. (2010).
} 
each other. If the prices of financial securities drop to a level, where they yield very high returns, say $15 \%$ as presently in Greece, lenders will attempt to obtain similar yields on new loans as well. Because in efficient markets the rates of return for given risks must be equalised, the default risk spread between sovereign debtors or relative to private debtors effectively becomes the risk of splitting up the currency area. On the other hand, a fully integrated European financial market with deep trading of Eurobonds, spreads would be minimised by arbitrage. But with fractioned financial markets, yield spreads are likely to overshoot default risks because of liquidity constraints and the real costs of fire-sales manifest themselves in deep regional credit crunches, as can presently be witnessed by the economic recession in the South of Europe. The banking union and efficient macroprudential regime must overcome these negative externalities caused by fractioned financial markets.

This poses the question why banks do not recapitalise quickly, when they are weakened by a shock. One problem is the debt overhang problem, which results from the fact that senior creditors may siphon off the value of new equity instead of rechanneling invested funds towards profitable investment opportunities (see Myers, 1977). Given the debt overhang problems, banks act in the interest of their shareholders when they deleverage instead of raising new capital even if the latter would be desirable from a social perspective. Secondly, Stein (2010) has also argued that banks will not build up adequate buffer stocks of capital when short-term debt is cheaper than equity. In this case they do not internalise all of their costs. In particular, when a bank takes on more debt, it does not account for the fact that by doing so it may degrade the collateral value of any asset it holds in common with other banks, since in a crisis the first bank's asset fire sales of will lower the liquidation value that can be realised from these assets for all others. ${ }^{16}$

To summarise, fire-sales and credit crunches generate strong incentives for deleveraging the balance sheet ex-post in a crisis and to operate too thin capital buffers ex-ante. They thereby increase the probability of a system-wide balance sheet contractions and an eventual crisis. The purpose of macro-prudential regulation is to correct these two tendencies.

\subsection{A single supervisory system}

In the European Union three supervisory authorities have started their work on 1 January 2011:

- the European Banking Authority (EBA) deals with banking supervision including recapitalisation of banks,

- the European Security and Markets Authority (ESMA) deals with the supervision of capital markets,

- the European Insurance and Occupational Pensions Authority (EIOPA) deals with insurance supervision.

In addition the European Systemic Risk Board (ESRB) focuses on macro-prudential oversight of the financial system within the Union.

While these institutions preserve important regulatory functions, it is now envisaged to give sweeping powers to the ECB (European Commission, 2012a), covering the more than 6,000 banks, bank-led financial conglomerates (including bank assurers) and financial holding companies in the euro area.

According to O'Sullivan and Kinsella (2012):

\footnotetext{
${ }^{16}$ See Hanson et al (2010).
} 
'The ECB would be responsible for all aspects of prudential supervision - from authorisation, ongoing supervision at the start and early intervention during times of crisis to the withdrawal of bank licences where appropriate. It would assume key powers from national prudential supervisors, including national supervisory discretions, such as the imposition of higher capital and liquidity buffers to address specific systemic risks at the national level. It would become both 'home' and 'host' supervisor for banks operating across borders in the EZ. It would have power to access a bank's corporate governance and risk management processes and systems to ensure that it meets with best practice standards. [...] The ECB would be able to intervene directly with any bank in the EZ. National supervisors would only retain primary responsibility for protecting consumers and preventing financial crime at the national level.'

In short, the supervisory agency of the ECB would resemble a 'financial FBI', with the authority to overrule national legislation. Given the nowadays quasi-permanent political gridlock in the EU and crony-capitalism in some Member States, this development is welcomed to restore financial stability.

Nevertheless, the issue of supervision by the ECB has been controversial for the last the least twenty years. While the European Monetary Union initially followed the German system and sought to separate monetary policy and supervisory functions, the new arrangement is now shifting the balance in the opposite direction. However, the arguments whether monetary policy and banking supervision are to be separated go back at least two centuries with the Bank of England standing for non-separation and the Prussian Bank, later the Reichsbank and Bundesbank, standing for separation regimes (Goodhart and Schoenmaker, 1995). The issue is whether the combination of monetary and regulatory functions under one roof leads to conflicts of interests. Proponents of the division of functions argued that concerns with the stability at the macro-level of the banking system may distort the central bank's conduct of monetary policy by creating excessive liquidity and undermining price stability. Proponents against separation insist on the central bank's objective of preventing systemic risk, which is also stipulated in the Treaty of the European Union as one of the tasks for the ECB.

Historical evidence has shown that the conflict of interests can exist when the central bank resists interest rate increases for fear of further de-stablising the financial system. No doubt, this is presently a concern in the European Union. On the other hand, there is little evidence that liquidity creation under the lender-of-last-resort function, when central banks are lending to banks in distress, would generate inflation. It has been shown, however, that the dangers of conflict of interest are depending on the structure of the banking system; they are increasing the more a system depends on intermediaries which finance maturitymismatch positions through wholesale markets in a competitive environment (Goodhart and Schoenmaker 1995). Thus, in open competitive market-driven systems, there is a growing need to internalise externalities by a single authority. Given that European Monetary Union has opened national markets, generated economies of scale and increased competitive pressures, the move towards a single supervisor, putting the ECB in charge, reflects the realities of European Monetary Union.

However, counter-acting tendencies also exist. Greater competition could also make commercial banks less willing to participate in potential bailouts and the resolution of failing banks. Goodhart and Schoenmaker (1995) argue that this reduces the clout of the Central Bank in 'dragooning unwilling commercial banks to volunteer their participation in rescues'. A Central Bank may therefore be constrained in its capacity to intervene in financial rescues and needs to be supplemented by tax payers' money. These authors observe a trend towards using more public money in financial rescues over recent decades. However, 
Policy Department A: Economic and Scientific Policy

during the Euro crisis the willingness of Member States to provide the necessary finance through large rescue funds has been limited as the difficult ratification process regarding the EMS has shown. This reluctance by Member States governments to provide the backup for financial stability has pushed the ECB into the frontline. Because Member States refuse to act themselves as the lender of last resort to governments, the ECB is effectively forced to expand its function as lender of last resort to banks. By setting up the Outright Monetary Transactions (OMTs) programme, the ECB has been able to restore some confidence in financial markets, but clearly this is not a long-term sustainable solution to the dangers and threats resulting from financial instability. The systemic risks for the financial system need to be addressed by integrated macro policies for the euro area as a whole. Macroprudential supervision is one side of this problem; reducing the likelihood of regional booms and busts in the real economy is the other side.

18

PE 492.455 


\section{ECONOMI C UNI ON}

European authorities drew the policy conclusions from the Euro crisis that excessive borrowing and insufficient respect of the Stability and Growth Pact had contributed to the accumulation of unsustainable debt and that the system therefore needed tighter surveillance of national fiscal policies. This argument was soon supplemented by the realisation that excessive borrowing in the public and private sectors has led to rising debt and huge current account deficits. Debt brakes and austerity were then the answer and institutional reforms tightened fiscal policies and introduced a new procedure for avoiding regional imbalances, especially for deficit countries.

Macroeconomic policies play an important role in preserving financial stability and inversely. As one could witness during the Euro crisis, systemic financial malfunctioning can quickly spill over into the real economy. When fire-sales lead to credit crunches, investment and economic growth in the real economy will slow down or go in reverse. However, the process does not stop there. As the economy starts retracting, banks will have to write off bad debt. Financial asset prices will further contract. Additional fire-sales will follow and the credit crunch will worsen. This negative downward spiral needs to be stopped. The problem is worse, the higher the financial leverage has become and the more financial markets are segmented. However, some leverage is also beneficial, because it stimulates investment. To find and maintain the right balance between too high and too low leverage levels, a surveillance procedure not only for public debt, but also for private credit booms would be recommendable for the euro area. This is in essence, what the new Macroeconomic Imbalance Procedure (MIP) should try to achieve, while the new fiscal framework will put the breaks on public debt.

Nevertheless, once a financial crisis has developed, urgent short run policy measures are necessary in order to break the vicious circle of fire-sales and deleveraging. In this context, and maybe only in this context, fiscal policy could play an important role for growth by slowing down the market-driven deleveraging process and by stimulating effective demand. Yet, with high and rising debt, the implementation of such policies seems difficult. Europe's austerity drive clearly goes into the opposite direction. It is therefore necessary to place macroeconomic stabilisation policies in a long-run institutional context of efficiency and legitimacy. But this is not happening. To understand why, we will first deal with the imbalances and then discuss fiscal policy in the next section.

\subsection{Regional imbalances}

The private debt dynamic in Europe is not tackled by any explicit policy procedure, although the Macroeconomic Imbalance Procedure (MIP) claims to do so implicitly. It relies on an alert system that uses a scoreboard of indicators and in-depth country studies and sets up rules for national macroeconomic policies together with a rule enforcement and financial sanctioning mechanism. The problem here is that the new policy tool focuses on the external debt of Member States, rather than on the domestic credit accumulation in specific sectors and regions, such as the construction industry. Instead of dealing with the flow of funds between economic sectors of the euro area, and monitoring them properly, the policy focus on regional imbalances and national current accounts or external indebtedness prevents the design of a coherent macroeconomic policy for the currency area. Simple rules like balancing the current account deficits simply re-enforce austerity and the risks of financial instability (see Collignon, 2012d).

Most discussions on regional imbalances within the euro area have probably concentrated on national current account imbalances, because Member States still record these 
statistics. ${ }^{17}$ The Macroeconomic Imbalance Procedure Scoreboard lists current account statistics as the first priority for assessing imbalances. This emphasis reflects a shift in economic thinking. In the early phase of monetary union, current accounts were considered to have lost their significance within the same currency area, just as we do not give any attention to trade and payment imbalances within nation states. But in the recent crisis, Member States are again being treated as 'foreign' and arguments that current accounts matter have been resuscitated by the revisionist literature. ${ }^{18}$ In essence the argument hinges on the claim that due to an excess of spending over income, southern Member States have accumulated large and unsustainable external debt. While it is obviously true, that excessive debt could cause defaults which would destabilise the system, it is not necessarily correct that a Member State in monetary union could only service the debt by export surpluses, because, given that the Euro is the common currency, sufficient domestic growth in the local economy would generate the income to service Euro debt. However, as explained earlier, regional slumps may reduce the economic growth necessary to preserve the stability of the banking system and it is therefore important to avoid severe regional recessions from destabilising the monetary union as a whole. The real issue is therefore the disparity in growth, not current account imbalances.

What determines growth in the long run is a complex issue, with which economists are still struggling (Helpman, 2004). No doubt, structural reforms to improve total factor productivity and the potential productive capacity are the most important factor in the long run. However, in the short- and medium-term, excessive spending or austerity can cause booms and busts, which undermine financial stability and hamper long-term growth. What causes such excesses? Policy mistakes may be one factor, but institutional shortcomings are more important.

A frequent criticism of monetary union has been formulated by the Walters critique, which explained regional imbalances as the manifestation of the pro-cyclical impact of regional inflation rates on the economies of Member States. The argument goes like this: with a unified bond market, nominal interest rates are equalised for similar risk classes and regional deviations of inflation from the euro area average would therefore translate into different real interest rates. While these assumptions may have been valid during the first ten years of European Monetary Union, the Greek crisis and the subsequent disturbances in financial markets have clearly shown that financial markets often under- or overshoot in their assessment of default risks. Thus, it is not only inflation but also yield spreads that can create severe distortions. The reasons for these malfunctioning are precisely the firesale and credit crunch phenomena discussed earlier. However, Walters' argument that differences in national real interest rates may amplify imbalances deserves attention.

While the Walters critique has led to the conclusion that pro-cyclical movements in real rates may render monetary union unsustainable, Angeloni and Ehrmann (2004) and Mongelli and Wyplosz (2008) have noted that the critique has overlooked international competition. While higher inflation in particular Member States lowers real interest rates and fuels booms, the rising prices deteriorate competitiveness. They reduce the returns on capital for the whole region, increase trade deficits and ultimately necessitate a costly adjustment of relative prices within the euro area. Yet, the Walters critique may still be valid, if regional growth divergences respond more strongly to real interest rates than to relative price and cost distortions. To check for this possibility, our annex reviews the

\footnotetext{
17 See Directive of 12 January 2005 on Community statistics concerning balance of payments, international trade in services and foreign direct investment: http://circa.europa.eu/Public/irc/dsis/bop/library?l=/sdds bop metadata/bop regulationpdf/EN 1.0 \&a=d.

18 For a review of the literature see Collignon 2012b.
} 
evidence for the entire period since the European Monetary Union started in 1999, and estimates an econometric model of the (competitiveness-modified) Walters critique.

In these estimates, we have taken the deviation of Member States' growth rates from the average euro area as our independent variable and explained its performance by the real interest rate and an indicator for unit labour costs competitiveness that derives equilibrium from the relative returns on capital in the euro area. ${ }^{19}$ The Walters critique is not always clear about what kind of interest rates should be considered as relevant. Short-term interest rates are obviously set by the ECB and therefore identical for banks in all Member States, so that short-term real interest rates directly reflect inflation. On the other hand, investment is usually assumed to depend on long-term rates and these have diverged dramatically during the Euro debt crisis. We have therefore tested for the role of both sets of rates in our econometric estimates. We also have tested interest spreads and nominal rates with inflation separately. We have also tried to include a variable for budget deficits although it did not work under the established criteria of econometric significance.

The results of the estimates, which are shown in the Annex, indicate that growth differentials within the euro area are strongly dependent on the spread between short and long run interest rates (columns 1 and 4 first panel). Because inflation cancels out in the spread, it is not monetary but financial instability, which causes regional imbalances. When separating the two real interest rates (columns 2 and 5), both variables turn insignificant, while on the other hand nominal rates as well as inflation are significant in specification 3 and 6. According to these results, an increase in either the long-term or short-term interest rates reduces the relative growth and a similar effect is exerted by the inflation rate. The effects of inflation suggest reverse causality between real growth and inflation. Finally, as to the control variables, both competitiveness and budget balances are significant and of the expected sign, although the effect of fiscal policy is extremely small. Summing up, our results do not find any confirmation of the Walter's critique in the euro area but support the Angeloni and Ehrmann (2004) and Mongelli and Wyplosz (2008) hypothesis of excessive imbalances being self-correcting through competitiveness pressures. Furthermore, they show that a genuine monetary union with a fully integrated financial market would reduce regional imbalances.

However, as we have witnessed during the Euro crisis, once the boom has turned into bust, the banking system starts deleveraging and credit crunches occur, which lead to an overshooting of the downward adjustment that is extremely painful and often takes a long time. A genuine monetary union should therefore have policy tools to prevent such socially destructive overshooting. Monetary union must be imbedded into a Social Union.

\subsection{Macroeconomic aspect of a European Social Union}

The Euro crisis has generated a new awareness for problems of social justice. European policy decisions alter the allocation of resources so that European integration is not only about efficient and consensual policy outputs, but there is also competition over the distribution of inputs and outputs (Hix, 1998). This raises issues of justice and fairness. Often, they are discussed in the context of European welfare regimes (Stuchlík and Kellermann, 2009). The European Commission has formulated social agendas, which are pursued through the Open Method of Coordination and other soft cooperation tools. However, with respect to European Monetary Union, we will concentrate here only on how macroeconomic policy mechanisms can improve the functioning of the currency area and thereby reduce the social costs in terms of output losses, unemployment, price and financial stability and excessive tax burdens.

19 For a detailed description of the indicator see below, and Collignon, 2012b. 
There are two alternative although not mutually exclusive approaches to reduce regional disparities in order to maintain the income growth necessary to keep the financial system stable: stability oriented wage settlements and fiscal transfers.

Wage settlements have an important impact on the return on capital and therefore on the attractiveness for investment and the dynamics of economic growth. In an ideal economic world, the returns on capital in different regions would all be equal and we can take this norm as the benchmark for calculating the level of Unit Labour Costs (ULC) at which no regional distortions exist. Hence, this is a definition of equilibrium unit labour costs. Because we take the return on capital as our reference, wage settlements should take into account not only labour productivity, but also capital productivity. ${ }^{20}$ In equilibrium, the wage levels should be considered as just and fair.

Deviations from equilibrium are an indicator for macroeconomic imbalances, because they set the incentives for investment and growth. Figure 1 shows how actual and equilibrium unit labour costs have evolved. With the exception of Austria, most northern euro area Member States have unit labour cost levels below equilibrium level, hence capital returns above Euro average, while the opposite is true in the South. These calculations give a more accurate picture than the usual unit labour costs indices, which are also used by the Commission in the Macroeconomic Imbalance Procedure Scoreboard. For example, Italy is close to equilibrium because the relatively high wage increases (relative to productivities) have only eroded the advantage obtained by the large depreciations in the early 1990s.

Our methodology to calculate equilibrium unit labour cost level has implications for wage setting. First, wage settlements below equilibrium could shorten a recession or slow-growth period by generating incentives for higher investment and faster growth. This would be good not only from a social point of view, but it would also help to stabilise the banking union. Second, wage bargaining must become European. This does not mean that wage negotiations should be centralised at the European level, but it is important that national negotiators take into account the relative competitive position of their economy and the external effects their settlements will have for the national and European economy as a whole. Today, most of the less competitive economies in the south take the public sector as the leader, while in the north it is the tradable or export sectors that set the margins for wage increases. This inconsistency has contributed to the macroeconomic imbalances in the euro area. In a genuine monetary union, wage bargainers must be aware of the implications of their settlements for the euro area as a whole. This would also improve the sense of fairness and justice among citizens in the euro area.

20 For details see Collignon 2012b. 


\section{Figure 1.: Unit Labour Costs (ULC) relative to euro area}

ULC relative to Euro Area: actual and equilibrium
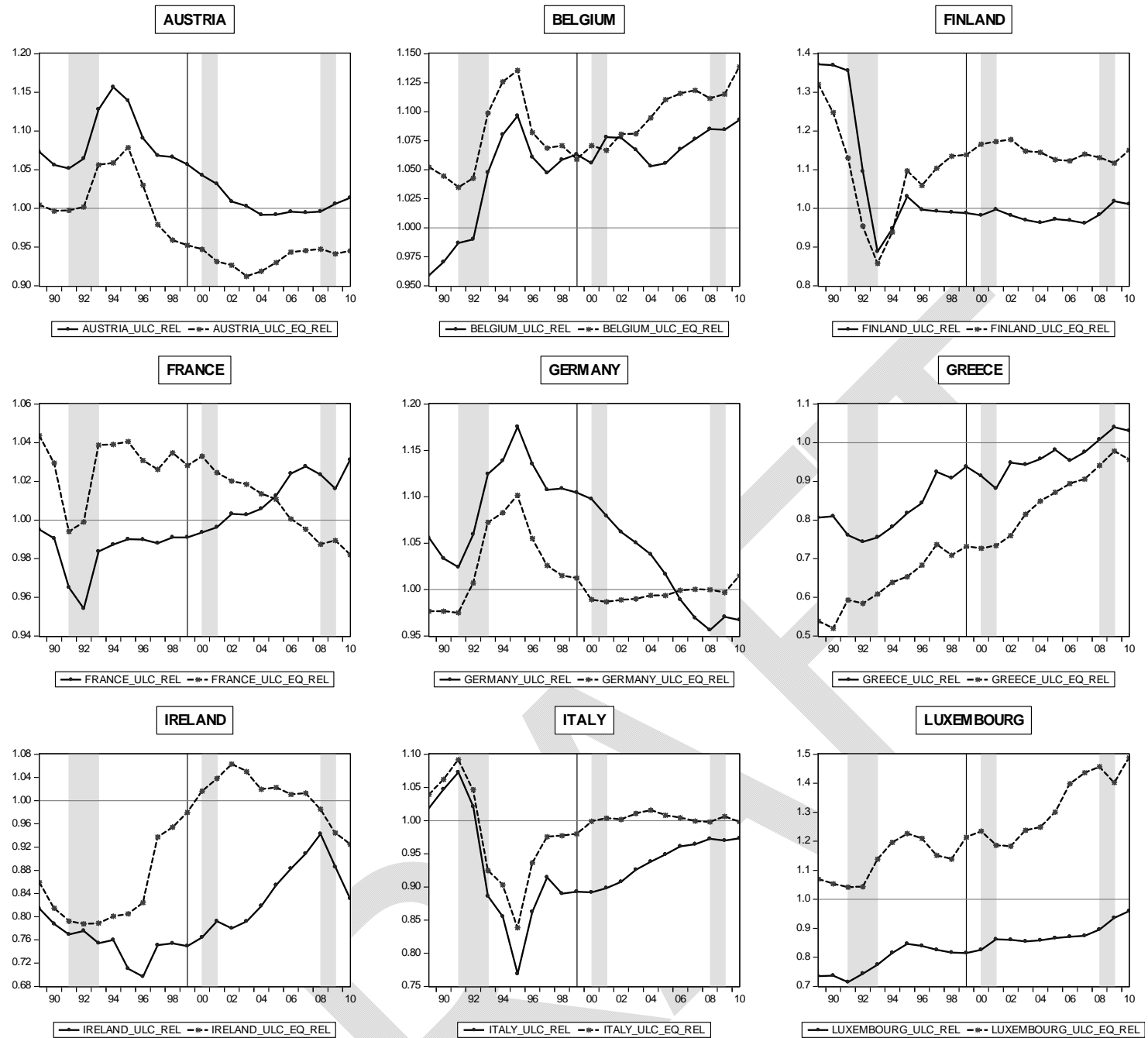

-IRELAND_ULC_REL - - - IRELAND_ULC_EQ_REL

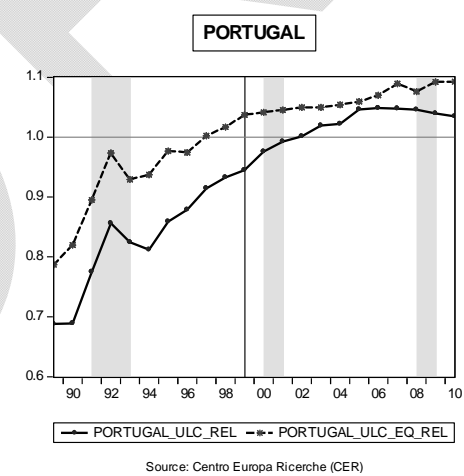

- LUXEMBOURG_ULC_REL - - - LUXEMBOURG_ULC_EQ_REL
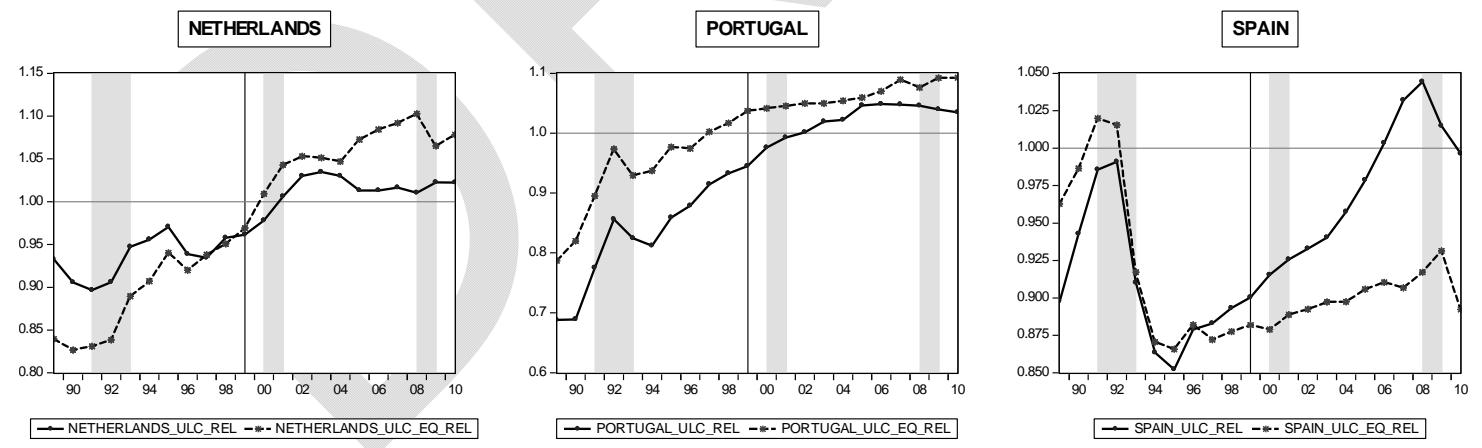

Source: Centro Europa Ricerche (CER). 


\section{FISCAL UNI ON}

The second major policy tool to reduce growth imbalances is fiscal policy. Here, too, important institutional reforms have taken place. The 'Six-Pack' rules entering into force on 13 December 2011 have, inter alia, beefed up the Stability and Growth Pact (SGP). The European Semester, starting with the publication of the Annual Growth Survey by the Commission, provides a framework for economic policy coordination in general. A rule has also been established for the speedy reduction of debt ratios and therefore making now the debt criterion operational. Sanctions against Member States under the EDP will be adopted on the Commission's proposal except if a 'reverse majority' opposes it. The Treaty on Stability, Coordination and Governance (TSCG), signed by 25 EU Member States, sets a new cap on structural deficits. Member States must implement a 'debt brake' into national law lest they risk being sued in the European Court of J ustice.

However, it is far from being clear that these new rules and procedures will produce optimal results, as Aiginger et alt. (2012) have argued:

- For some countries, fiscal targets are not realistic and, given the slow or negative growth, they will most probably be breached. This could re-ignite financial instability.

- Tighter fiscal rules will shift the priorities away from long-run structural reforms under the Europe 2020 Strategy and therefore reduce catch-up growth.

- Collective austerity hampers growth and investment in the euro area as a whole, thus making compliance with rules even harder.

- The toxic combination of potentially spiralling interest rates, negative growth and rising unemployment is continuing with the risk that the ECB would no longer be able to hold the financial system together.

- The 'reverse majority' leaves the problem of 'unenforceable' fiscal rules unresolved for large Member States and re-enforces the democratic deficit unless the role of the European Parliament is significantly strengthened.

Here is not the place to discuss the correctness of the official analysis and its critics, although evidence points at a slightly more complicated reality than the official policy line proclaims; northern Member States like Germany and France have increased their debt ratios during the first decade of European Monetary Union, while most of the southern Member States, in particular Spain and Ireland have seen their debt ratio fall. Nevertheless, all the institutional and practical responses to the crisis have one fundamental weakness in common, which is also shared by many critiques: they discuss Member States' fiscal policies as a partial equilibrium without taking into consideration the aggregate dimension of fiscal policy for the euro area as a whole. The focus on imposing fiscal consolidation and balanced structural deficits on each and every Member State prevents the euro area from using fiscal policy as a proper policy tool, by which aggregate demand is efficiently adapted to the potential growth path of euro area output. As a consequence, aggregate demand is not sufficient to stimulate investment and return GDP to pre-crisis levels. Not by coincidence is the economic performance of the euro area lagging behind the United States. The policy framework in the euro area is therefore inefficient in welfare terms. In the long run, this inefficiency will undermine the legitimacy of European integration.

The Van Rompuy Interim Report $(2012)^{21}$ may have realised these shortcomings when it emphasised:

21 See European Council (2012), The President, Towards a Genuine Economic and Montetary Union, Interim Report, 12 October 2012;

http://www.consilium. europa.eu/uedocs/cms data/docs/pressdata/en/ec/132809.pdf. 
'The crisis has underlined the high level of interdependence between euro area countries and even beyond. It has shown that national budgetary policies are a matter of vital common interest. This points the need to complement the current framework for the surveillance and coordination of budgetary policies with a more ex ante coordination framework, as proposed in the 'Two-Pack', and to move gradually towards a fully-fledged integrated budgetary framework. This will ensure sound budgetary policies at the national and European levels and thereby contribute to sustainable growth and macroeconomic stability.'

\subsection{The efficiency and legitimacy of budgetary policy in Europe}

This brings us to the core problem of fiscal policy in the euro area. It has to meet two challenges: efficiency and legitimacy. Efficiency means, a single currency union requires the definition of an aggregate fiscal policy stance. In federal unions, this stance is provided by the federal budget. Yet, the budget of the European Union is not even 1 percent of GDP, while government spending by Member States varies between one third and one half of GDP. This makes it impossible for the Union budget to act as a shock absorber, while national budget policies can cause major disturbances for the euro area as a whole. The Stability and Growth Pact does not solve this problem, because it only sets maximal limits for debt and deficits without defining a coherent macroeconomic fiscal stance that could manage short-term demand growth. Legitimacy, on the other hand, means in the present framework that fiscal policy is authorised by national parliaments, but, as the crisis has proven, the external effects of national budgets can be huge. This creates a wedge between economic efficiency and democratic legitimacy. I will first discuss the problem of the fiscal stance and then deal with legitimacy issues in the next section.

Fiscal policy in monetary union is inefficient, because it cannot be used as a tool to stabilise macroeconomic developments in the euro area as a whole as long as nation states are autonomous. Autonomous decisions made by sovereign nation states generate externalities for other Member States. As long as countries have separate currencies, these effects are absorbed by exchange rate variations. By contrast, in monetary union uncoordinated fiscal policies in one region affect the flow of funds within the euro area as a whole (Collignon, 2012d) with inevitable consequences for all other regions. In other words, national autonomous fiscal decisions generate externalities which affect all citizens in the euro area. The euro area has no mechanism to internalise these externalities other than the Stability and Growth Pact. Yet, the Pact is not a policy tool that integrates the fiscal positions of all Member States. It only establishes constraints for national policy makers. These constraints have no real democratic legitimacy, because European citizens are 'taxed by events' without having representation and choices. This system violates the norms of democracy.

From an efficiency point of view, the foremost priority must be the integration of national budgets and the European budget with the requirements of macroeconomic stability in the euro area. This requires the definition of an aggregate European fiscal position for the euro area as a whole. As I have pointed out in a previous report to the European Parliament's Economic and Monetary Committee (Collignon, 2010 and Collignon, 2004), one way to do so would be to define an aggregate budget deficit for the euro area and then to allocate appropriate shares of these aggregates to individual Member States. I repeat the idea here ${ }^{22}$ :

- Because it has external effects, the aggregate fiscal policy stance should reflect the macroeconomic conditions of the whole euro area, but also national preferences for the allocation of resources. Because fiscal policy can stabilise the currency area by

22 This idea was first outlined in Collignon (2004), Chapter 4: Integrating European and National Budget Policies; http://oenb.at/de/img/ws 4 tcm14-24704.pdf. 
balancing aggregate demand expressed in money with aggregate supply valued in current prices, it must determine the aggregate net borrowing requirement in the euro area. In order to be able to respond to the policy preferences of all citizens, it must also be democratically controlled by an institution that represents collective preferences, i.e. the European Parliament.

- Once the aggregate deficit is defined at the European level, each jurisdiction is assigned a share of this total deficit. Within their assigned quota, national governments are free to set their priorities in response to their voters' preferences.

- 'Technically the procedure of first defining the macroeconomic aggregate and then its micro application in a second step is not unusual. For example, the French Parliament votes first a macroeconomic framework law, so that the subsequent detailed item voting within the overall budget constraint (les arbitrages) ensures that specific preferences remain coherent with the overall stability requirement. Similarly, the budget process in Italy defines first the multi-annual macroeconomic framework law, the Programmazione Economico e Finanziario (DPEF), and then the legge finanziaria, which implements the actual budget allocations. ${ }^{23} .{ }^{24}$ In our proposal, the macroeconomic stance is voted by the European Parliament and the Council, the micro-application by national parliaments.

- In the Euro-context, a European Directive, subject to the ordinary legislative process (Art. 294 TFEU) and possibly restricted to euro area Member States, is the appropriate instrument for ensuring democratic control. Its purpose is to define a binding annual macroeconomic framework law. Such a directive could use the Broad Guidelines of Economic Policies (BEPG), defined in Art. 121 TFEU, and transform them into secondary legislation.

- These reformed guidelines would authorise aggregate spending and income targets for all EU public authorities (from municipalities to regions, nations and the EU budget) in accordance with the requirements for the stabilisation of the business cycle and possible regional excesses or shortfalls of demand, but also with respect to intergenerational burden sharing in accordance with the limits on national debt.

- These reforms would effectively define the aggregate budget deficit of the European Union for any given year. This would ensure vertical flexibility of Europe's fiscal policy with respect to the aggregate and horizontal flexibility with respect to national fiscal policies. At the same time, the involvement of the only representative chamber of citizens is the guarantee of democracy.

This assessment is still relevant, although it finds little echo in the Council deliberation.

\subsection{A budget for the euro area?}

A second approach for improving the role of fiscal policy for macroeconomic stability consists in expanding the budgetary capacities of the euro area. This is an important innovation in the Van Rompuy Interim Report (2012) and deserves to be quoted:

'One of the functions of such a new fiscal capacity could be to facilitate adjustments to country specific shocks by providing for some degree of absorption at the central level. In the EMU, the response to a symmetric shock affecting all countries simultaneously should primarily be provided by monetary policy, whereas in the context of country-specific economic shocks, the response falls primarily on national budgets. The European Stability Mechanism is a crisis management instrument and was not designed to perform such a shock absorption function. Moreover, low levels of cross-country labour mobility and structural impediments to price flexibility make

\footnotetext{
23 Collignon (2004).

24 Amato, G. 2002. Verso un DPEF Europeo; NENS No.4 (Nuova Economia Nuova Società), luglio, p.15-19.
} 
economic adjustment mechanisms less effective than in other monetary unions. Asymmetric shock absorption at the central level would represent a form of limited fiscal solidarity exercised over economic cycles, improving the economic resilience of the EMU. Elements of fiscal risk sharing can and should be structured in such a way that they do not lead to permanent transfers across countries or undermine the incentive to address structural weaknesses.'

The newly created fiscal capacity is not incompatible with defining an aggregate fiscal stance as proposed above, but it would be used to deal explicitly with shocks by transferring funds to Member States that are experiencing severe recessions in order to stimulate investment and growth. In a different version, it could also be structured as a mechanism that improves the effects of automatic stabilisers, for example by setting up a European-wide basic unemployment insurance (Dullien, 2007; Schwarzer and Dullien, 2007).

However, the recent experience with the European Union budget has shown that, as long as Member States remain in charge of funding, such contributions to the general welfare of the European Union are handicapped, because collective action problems and free riding temptations will inhibit optimal outcomes. National governments cannot justify to their electorates why they should be paying for the preferences and policy mistakes of other nations. To overcome these obstacles, such funds must be a collective effort by all citizens concerned. They would have to be sourced by a proper European tax that is authorised by all European citizens collectively and technically the outcome of the ordinary legislative procedure (Art. 294 TFEU). This would give the European Parliament a decisive vote because it represents the collective interests and preferences of all European citizens, irrespective of national gerrymandering. Such a procedure would be efficient and democratically legitimate. It would liberate the euro area of the domination by national governments and their bureaucracies and the resulting inevitable inefficiencies. To achieve this is the ultimate challenge of a genuine European monetary union. 


\section{A DEMOCRATIC POLITICAL UNI ON}

Ultimately, the biggest obstacle to a genuine European monetary union is the lack of democracy at the European level, because without democratic consent efficient policies cannot be implemented. But the segmentation of national polities in the euro area prevents the emergence of border-transcending consensus. The problem of democratic legitimacy is generated by the fact that European citizens could not collectively decide a fiscal position that would legitimise policy makers to set fiscal positions in support of efficient macroeconomic management of the euro area. Democracy does not come in little pieces. It is government by the people, for the people, through the people, although 'people' does not necessarily mean 'demos' or 'Volk', but simply the set of citizens concerned. Economic choice models can show that if a simple policy rule, such as balancing structural deficits, is not shared and accepted by a democratic consensus in each and every Member State, large groups of European citizens will always see their collective preferences being frustrated. But this is the rule rather than an exception if governments are elected nationally whereas policies are made at the European level. This would be different, if a mechanism for democratic choice existed at the European level, because citizens could consider themselves as the sovereign who makes the ultimate choice and therefore could change policy directions. Thus, lack of democracy is a continuous source of political disenchantment with euro area policies (Collignon, 2008).

However regrettable these shortcomings may be, they are deeply rooted in the political system, which governs the euro area. While monetary policy has been delegated to a federal institution, namely the ECB, fiscal policy has remained under the exclusive authority of Member States, even if the Stability and Growth Pact has established certain limits, which Member States must respect. Although it is inefficient, this attribution of competences is not surprising. By keeping fiscal policies under exclusive national responsibility, the governance of the euro area respects the principle: 'no taxation without representation.' National parliaments alone have the legitimacy to establish national budgets, expenditures, taxes and borrowings. But the externalities caused by national decision can become more than a minor nuisance: they have threatened the very survival of the monetary Union.

Thus, the Euro crisis has revealed one certainty: Europe's model of governing its single currency is not sustainable in its present form. The essence of this crisis consists in a contradiction between the deep integration which has been achieved on economic issues, and the shallow political integration which has maintained the 'sovereignty' of Member States. This contradiction needs to be solved, for if the Euro fails, the European Union will disappear as well as we have argued in Section 2.

The reason for such disturbing judgment is simple: politics is the Achilles' heel of Monetary Union. Abolishing economic obstacles and restrictions in the internal market, while maintaining regulatory chaos through the existence of externalities-creating national governments, is incoherent. History teaches that in order to reproduce itself, a society needs norms and rules that are coherent and do not contradict each other, because these norms and rules give orientation and purpose to the actions of individuals. But if the norms which govern politics and the economy are inconsistent, the institutional system of any society becomes dysfunctional and will ultimately be dismantled. This is the danger for the European Union today. The economic integration in a single market with a single currency requires macroeconomic policies that are able to give a coherent framework for internalising the externalities resulting from individual actions and national policies and managing the common interest. But Member States seek to preserve regulatory advantages and minimise spending on common public goods. As a consequence, people are 
confused and tempted to return to a system of independent nation states where they knew how things worked.

The alternative to dismantling the European Union is setting up a government that will administer European public goods, but only those goods. In the euro area, this means in substance setting up an economic government. But in order to be coherent with the values and norms which have emerged over the course of European history, such a government must be democratic. That means that policies are made by the people, for the people, and through the people. Unfortunately, the European Union may be making policies for the people (although even that is increasingly disputed), but it does not give all European citizens a right to decide for themselves the orientation of policies that are implemented. Austerity policies are made by the Council and the Commission; in some Member States economic policy is made by the Troika; some even argue that policies are imposed by Germany. This system is in profound contradiction with the most fundamental norm of the European Union, namely democracy. It is of course true that the policies agreed by European institutions are formally legitimised by democratically elected governments. But while intergovernmentalism is legitimate in the case of foreign policies between independent nation states which share few common public goods, it is no longer functional or justified when all citizens share the same hard budget constraint of one currency and are affected by externalities in the most essential conditions of their lives. Macroeconomic policy has effectively become domestic, European politics has not.

There is presently much talk about a 'federalist leap' necessary for the survival of the euro. However, it is not clear what federalism means. The name covers two diametrically opposed policy visions. The Swiss-German tradition sees the benefits of federalism in decentralisation and subsidiarity of political decision making (Burgess, 2000); the US American tradition of the Federalist Papers has insisted on the need for a central government in order to overcome collective action problems (Dougherty, 2003). Musgrave (1973) has differentiated between the allocation, stabilisation and re-distribution function of government and argued that decentralisation is only efficient for the allocation function, while the stabilisation and re-distributive functions should be centralised. This theory, which is widely accepted by economists, would recommend stronger centralised functions for the kind of issues we have discussed in this paper.

Nevertheless, more delegation of policy competences to the European level encounters opposition on democratic grounds. The Troika may act as a centralised European policy making unit, but it has not been legitimised by European citizens who chose the policies they want to see applied. Further centralisation would only increase the democratic deficit in the EU. For the moment, Europe is muddling through this issue by repeating national elections or referenda until the results conform to the dominant policy consensus of the elites. This will not go on for long. Already, finding policy solutions is becoming increasingly difficult. It therefore becomes clear that efficient policies for a genuine European monetary union will only work, if the federalist leap is matched by a leap into a genuine democratic political union. This means European citizens must have a right to choose between economic and other policies that are affecting their daily lives. Not more, not less. I call this form of democratic government the European Republic. Unless this normative contradiction between efficiency and democracy is solved, there is little hope that the European Union will survive. 


\section{REFERENCES}

- Aiginger, K., O. Cramme, S.Ederer, R. Liddle, R. Thillaye (2012), Reconciling the short and the long run: governance reforms to solve the crisis and beyond; European Policy Brief No. 1, September; Bruxelles.

- Amato, G. (2002), Verso un DPEF Europeo; NENS No.4 (Nuova Economia Nuova Società), luglio, p.15-19.

- Angeloni, I., and M. Ehrmann (2004) Euro Area Inflation Differentials, Working Paper, 388, European Central Bank., Frankfurt.

- Blanchard O and Giavazzi F (2002), Current Account Deficits in the Euro Area: The End of the Feldstein Horioka Puzzle. Brookings Papers on Economic Activity 33(2): 147-210.

- Burgess, M. (2000), Federalism and European Union: The Building of Europe, 19502000; London and New York, Routledge.

- Collignon, S. (2004), Fiscal Policy and Democracy in Europe, in: Workshops Proceedings of OeNB Workshops: A Constitutional Treaty for an Enlarged Europe: Institutional and Economic Implications for Economic and Monetary Union, 5 November 2004; http://oenb.at/de/img/ws 4 tcm14-24704.pdf.

- Collignon, S. (2008), Why Europe is Not Becoming the World's Most Competitive Economy. The Lisbon Strategy, Macroeconomic Stability and the Dilemma of Governance without Governments; International J ournal of Public Policy, Vol. 3:1/2.

- Collignon, S. (2010), Bureaucratic Suppression of National Sovereignty in the European Union? Ideas on the Multilateral Surveillance Regulation, Briefing Paper European Parliament, 08 September 2010;

http://www. europarl.europa.eu/document/activities/cont/201009/20100908ATT81692/ 20100908ATT81692EN.pdf.

- Collignon, S. (2010b), Europe's economic government or how to use the Treaty for more effective economic coordination in the euro area? Note to the European Parliament's Committee on Economic and Monetary Affairs. 8 March 2010.

- Collignon, S. (2012), ECB Interventions, OMT and the Bankruptcy of the No-Bailout Principle. Note to the European Parliament's Committee on Economic and Monetary Affairs. IP/A/ECON/NT/2012-05 September.

- Collignon, S. (2012b), Macroeconomic imbalances and comparative advantages in the Euro Area; European Trade Union Institute (ETUI), Brussels, 2012. Download from: www.stefancollignon.eu.

- Collignon, S. (2012c), Europe's Debt Crisis, Coordination Failure and International Effects. ADBI (Asian Development Bank Institute) Working Paper Series, No. 370, July 2012.

- Collignon, S. (2012d), Macroeconomic imbalances and competitiveness in the Euro Area; Transfer: European Review of Labour and Research, forthcoming.

- Collignon, S. and D. Schwarzer, (2002), Private Sector Involvement in the Euro. The Power of Ideas, Routledge, (with Daniela Schwarzer) Routledge, London.

- Collignon, S., P. Esposito and H. Lierse (2011), European Sovereign Bailouts, Political Risk and the Economic Consequences of Mrs Merkel. ARENA working paper. Download from: www.stefancollignon.eu. 
- Diamond DW and Dybvig PH (1983), 'Bank runs, deposit insurance, and liquidity'. J ournal of Political Economy, 91.3: 401-19.

- Dougherty, K.L. (2003), Madison's Theory of Public Goods; in: Samuel Kernell (ed), James Madison. The Theory and Practice of Republican Government. Stanford, CA. Stanford University Press.

- Dullien, S. (2007), Improving Economic Stability in Europe. What the Euro Area can learn from the United States' Unemployment Insurance. Working Paper FG 1, 2007/11 July, Stiftung Wissenschaft und Politik, Berlin.

- Eichengreen, B. (1991), Is Europe an Optimum Currency Area? NBER Working Paper No. 3579.

- European Commission, (1997), Commission Interpretative Communication Freedom To Provide Services And The Interest Of The General Good In The Second Banking Directive; Brussels, 20.06.1997. SEC(97) 1193 final

- European Commission, (2012), Towards a Banking Union; Press release. Reference: MEMO/12/656 Event Date: 10/09/2012; http://europa.eu/rapid/press-release_MEMO12-656 en.htm.

- European Commission (2012a), Council Regulation conferring specific tasks on the European Central Bank concerning policies relating to the prudential supervision of credit institutions, September.

- European Commission (2011), Press Release: Commission wants stronger and more responsible banks in Europe; Brussels, 20 July 2011, IP/11/915; http://europa.eu/rapid/press-release_IP-11-915_en.htm.

- European Council (2012), 28/29 June 2012, Conclusions. http://www.consilium.europa.eu/uedocs/cms_Data/docs/pressdata/en/ec/131388.pdf.

- European Council (2012), The President, Van Rompuy, H., Towards a Genuine Economic and Monetary Union, Interim Report; http://www.consilium. europa.eu/uedocs/cms_data/docs/pressdata/en/ec/132809. pdf.

- Friedman, M. (1969), Optimum Quantity of Money. Aldine Publishing Company.

- Goodhart, C. A. E. (1998), The two concepts of money: implications for the analysis of optimal currency areas; European Journal of Political Economy, 14: 407-432.

- Goodhart, C. A. E. and D. Schoenmaker (1995), Should the Functions of Monetary Policy and Banking Supervision Be Seperated? Oxford Economic Papers 47.4: 539-560.

- Gros, D. (2012), Banking Union: Ireland vs. Nevada, an illustration of the importance of an integrated banking system, CEPS Commentary,18 October.

- Hanson, S., A. Kashyap and J.C. Stein (2010), A Macroprudential Approach to Financial Regulation, Working Paper No. 10-29, The University of Chicago Booth School of Business.

- Helpman, E. (2004), The Mystery of Economic Growth, MIT Press.

- Hix, S. (1998), The study of the European Union II: the 'new governance' agenda and its rival, J ournal of European Public Policy, 5: 1, 38-65.

- Laeven, L. and F. Valencia (2012), Systemic Banking Crises Database: An Update; IMF Working Paper WP/12/163. 
- Masini, F. (2012), Endogenous and Exogenous Optimum Currency Areas Criteria. A Historiographical Assessment, paper presented at the Gide Conference, Nice, 7-10 J une, http://www.gredeg.cnrs.fr/colloques/gide/Papers/Fabio\% 20Masini.pdf.

- Mongelli, F.P. and C. Wyplosz (2008), The Euro at ten: Unfulfilled Threats and Unexpected Challenges; Fifth ECB Central Banking Conference 'The euro at ten: lessons and challenges',

http://www.ecb.int/events/pdf/conferences/cbc5/Mongelli_Wyplosz.pdf?6eaad582d8c07 415c9ca0fce2ed11750.

- Mundell, R. (1961), A Theory of Optimum Currency Areas, American Economic Review, 51(Nov.): 509-517.

- Mundell, R.A. (1998), The Case for the Euro, Parts I and II, 'The Wall Street Journal', March 24-25, 1998, p. A22.

- Musgrave R. and P. Musgrave (1973), Public Finance in Theory and Practice, New York: McGraw-Hill.

- Myers, S. C. (1977), Determinants of Corporate Borrowing, Journal of Financial Economics 5: 147-175.

- O'Sullivan, V. and S. Kinsella (2012), The Commission's proposal on bank supervisory powers for the ECB; Vox.eu 20 September.

- Padoa-Schioppa T. (1987), Efficiency, stability and equity: A strategy for the evolution of the economic system of the European Community. Brussels: European Commission, II/49/87.

- Riese, H. (2001), Bagehot versus Goodhart: Warum eine Zentralbank Geschäftsbanken braucht. In: Hajo Riese, Grundlegung eines monetären Keynesianismus, Ausgewählte Schriften 1964ß199, Band 1; Metropolis, Marburg 2001.

- Schwarzer, D. and S. Dullien, (2007), Integrating the macro-economic dimension into the EU budget: Reasons, instruments and the question of democratic legitimacy; EUConsent, August 2007.

- Stein, J. C. (2010), Monetary Policy as Financial-Stability Regulation; NBER Working Papers 16883.

- Stuchlík, A. and C. Kellermann (2009), Europe on the Way to a Social Union? The EU Social Agenda in the Context of European Welfarism; Friedrich Ebert Stiftung International Policy Analysis, January. 


\section{ANNEX}

\section{ASSESSI NG THE RELEVANCE OF THE WALTER'S CRITIQUE I N THE EURO AREA}

The aim of this Annex ${ }^{25}$ is to assess the relevance of the Walter's critique in the context of sovereign debt crisis within the euro area. To this aim we estimate the relation between GDP growth and real interest rates in a panel of euro area countries. According to the Walter's critique, countries with higher inflation should experience higher growth because inflation lowers real interest rates. Prior to the global financial crisis there was no evidence of such effect (see Mongelli and Wyplosz 2008), but with the explosion of the debt crisis and the sudden increase in nominal long-term interest rates in many southern European countries, the situation may have changed.

One issue that needs to be clarified is which interest rates we take into consideration. Short-term interest rates are obviously set by the ECB and therefore identical for banks in all Member States. On the other hand, investment is usually assumed to depend on longterm rates and they have diverged dramatically during the Euro debt crisis. We have therefore tested for the role of both sets of rates in our econometric estimates.

Real interest rates are obtained by subtracting annual inflation rates from nominal interest rates. We use the yield on 10 years Government bonds as a measure for long-term interest rates, while for short-term rates we use the rate on Main Refinancing Operations (MRO) set by the ECB. In order to test their effects on national growth differentials to the euro area we use the deviation of the growth rate from the euro area average (GDPdiff) as the dependent variable.

We estimate three different specifications for the relation between growth, inflation and interest rates as in the following equations:

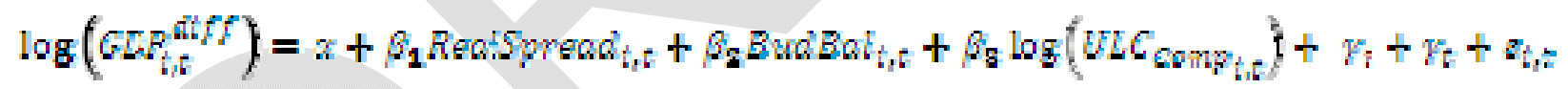

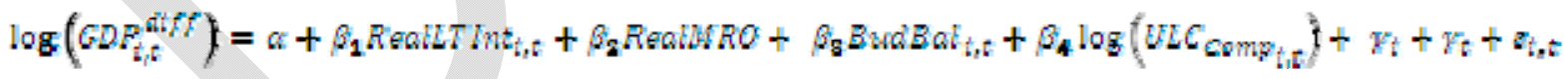

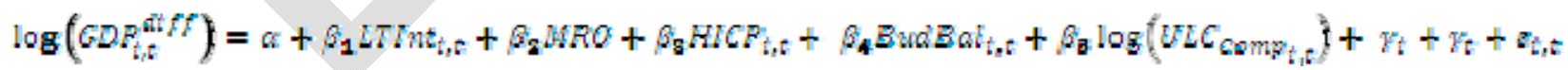

In equation (1) we simply introduce the real spread between long and short-term interest rates; in equation (2) we split the spread into its two components while in equation (3) we separate the effect of inflation (HICP) from that of nominal long- and short-term interest rates. In each equation we add the government balance in order to control for the effect of increasing deficits and a set of country and time dummies in order to account for country specific fixed effects and common shocks. The equations are estimates alternatively with the Fixed Effect estimator (FE), the Instrumental Variables Fixed Effects estimator and the

25 With research assistance performed by Piero Esposito. 
Common Correlated Coefficients Mean Group (CCEMG) estimator. While the use of an IV type estimator is justified by the potential endogeneity. The three equations are estimated for the original 12 members of the euro area over the period 1999 Q1 - 2012 Q2.

The estimation results are shown in Table A. 1 where the first 6 columns report the results with the standard fixed effects (FE) estimator and the following 6 the Instrumental Variables FE (IVFE) estimator. As to the latter estimator, we chose their first 3 lags as instruments for the endogenous variables in the case of columns 1-2-4-5 while for columns 3 and 6 we used only their first lag because of the failure to respect the overidentifying restrictions.

The results indicate that growth differentials within the euro area are strongly dependent on the spread between short and long run interest rates (columns 1 and 4 first panel) and the result is robust to the endogeneity (columns 1 and 4 second panel). In this specification the inflation rate does not enter the definition of the spread because is mutually eliminated from the two interest rates. When separating the two real interest rates (columns 2 and 5), both variables turn insignificant, while on the other hand nominal rates as well as inflation are significant in specification 3 and 6 . According to this result, an increase in either the long-term or short-term interest rates reduces the relative growth and a similar effect is exerted by the inflation rate in line with its standard effect. The effect of inflation, in any case, becomes insignificant after controlling for endogeneity, suggesting that the FE results are due to reverse causality between real growth and inflation. Finally, as to the control variables, both competitiveness and budget balance are significant and of the expected sign, but when these variables are treated as endogenous their significance diminishes or vanishes at all.

Summing up, our results do not find any confirmation of the Walter's critique in the euro area, although some shortcomings in the econometric procedure must be taken into account. First, the possibility of a rising importance of the Walter's critique in the last 3 years should be better investigated by a structural break analysis, for which the sample size is, in any case, too small. Second, the difficulty to disentangle the effect of the increased default risk on the yields from the structural effect due to fundamentals and to the creation of the single currency. 
Table A.1.: Estimation results of equations (1)-(3)

\begin{tabular}{|c|c|c|c|c|c|c|c|c|c|c|c|c|}
\hline & Fixed Efi & ects estim & ator & & & & Instrume & ntal Var & bles Fixed & Effects $\mathrm{e}$ & stimato & \\
\hline & 1 & 2 & 3 & 4 & 5 & 6 & 1 & 2 & 3 & 4 & 5 & 6 \\
\hline Real Spread & $0.005^{* * *}$ & & & $\overline{0.005 * * *}$ & & & $\overline{0.005 * * *}$ & & & $\begin{array}{l}- \\
0.006 * \\
* *\end{array}$ & & \\
\hline & {$[0.001]$} & & & {$[0.001]$} & & & {$[0.001]$} & & & {$[0.001]$} & & \\
\hline Real LT I nt & & -0.001 & & & 0.000 & & & 0.002 & & & 0.002 & \\
\hline & & {$[0.002]$} & & & {$[0.002]$} & & & {$[0.002]$} & & & {$[0.002]$} & \\
\hline Real MRO & & 0.001 & & & 0.001 & & & -0.003 & & & -0.002 & \\
\hline & & [0.002] & & & {$[0.003]$} & & & {$[0.003]$} & & & {$[0.003]$} & \\
\hline LT int & & & $-\overline{0.005 * * *}$ & & & $-\overline{0.005 * * *}$ & & & $-0.006 * * *$ & & & $-0.008 * *$ \\
\hline & & & {$[0.001]$} & & & {$[0.001]$} & & & {$[0.001]$} & & & {$[0.003]$} \\
\hline HI CP I nflation. & & & $-0.001 * *$ & & & $-0.001 * *$ & & & -0.001 & & & 0.002 \\
\hline & & & {$[0.000]$} & & & {$[0.000]$} & & & {$[0.001]$} & & & [0.003] \\
\hline MRO & & & $\begin{array}{l}-0.013 * * * \\
{[0.001]}\end{array}$ & & & $\begin{array}{l}-0.013 * * * \\
{[0.001]}\end{array}$ & & & $\begin{array}{l}-0.013 * * * \\
{[0.001]}\end{array}$ & & & $\begin{array}{l}-0.014 * * * \\
{[0.003]}\end{array}$ \\
\hline Log(ULCcomp) & $\begin{array}{l}-0.040 * * \\
{[0.011]}\end{array}$ & $\begin{array}{l}-0.043 * * \\
{[0.016]}\end{array}$ & $\begin{array}{l}-0.044 * * \\
{[0.014]}\end{array}$ & $\begin{array}{l}-0.038 * * \\
{[0.010]}\end{array}$ & $\begin{array}{l}-0.039 * * \\
{[0.014]}\end{array}$ & $\begin{array}{l}-0.042 * * \\
{[0.014]}\end{array}$ & $\begin{array}{l}-0.023^{*} \\
{[0.014]}\end{array}$ & $\begin{array}{l}-0.022 \\
{[0.016]}\end{array}$ & $\begin{array}{l}-0.027^{*} \\
{[0.014]}\end{array}$ & $\begin{array}{l}-0.028 \\
{[0.018]}\end{array}$ & $\begin{array}{l}-0.008 \\
{[0.017]}\end{array}$ & $\begin{array}{l}-0.05 \\
{[0.040]}\end{array}$ \\
\hline Budget Balance & & & & $\begin{array}{l}0.000 \\
{[0.000]}\end{array}$ & $\begin{array}{l}0.000 * * \\
{[0.000]}\end{array}$ & $\begin{array}{l}0.000 * * \\
{[0.000]}\end{array}$ & & & & $\begin{array}{l}0.000 \\
{[0.000]}\end{array}$ & $\begin{array}{l}0.001^{*} \\
{[0.000]}\end{array}$ & $\begin{array}{l}-0.001 \\
{[0.002]}\end{array}$ \\
\hline R2 w & 0.978 & 0.976 & 0.983 & 0.978 & 0.977 & 0.983 & 0.974 & 0.971 & 0.983 & 0.974 & 0.97 & 0.972 \\
\hline $\mathbf{N}$ & 512 & 512 & 512 & 512 & 512 & 512 & 489 & 489 & 511 & 489 & 489 & 511 \\
\hline Hansen & & & & & & & 4.99 & 6.81 & $0.00^{a}$ & 5.57 & 6.04 & $0.00^{\mathrm{a}}$ \\
\hline
\end{tabular}

Source: Own calculations.

Note: $\quad$ Standard errors in brackets; $*$ significant at $10 \%$ level, $* *$ significant at $5 \%$ level, $* * *$ significant at $1 \%$ level. ${ }^{a}$ Equation exactly identified. 